\title{
ROLE OF ERP AND TOTAL QUALITY MANAGEMENT IN EDUCATION
}

\author{
Anurag Sinha ${ }^{1}$ \\ ${ }^{1}$ Affiliation not available
}

November 26, 2020

\section{Hosted file}

ERP.pdf available at https://authorea.com/users/378998/articles/495376-role-of-erp-andtotal-quality-management-in-education 